\title{
SYNCHRONIZATION OF OESTRUS IN HEIFERS WITH IMPLANTS OF PROGESTERONE
}

\author{
J. F. ROGHE \\ The Agricultural Institute, Grange, \\ Dunsany, Co. Meath, Ireland
}

(Received 8th February 1974)

\begin{abstract}
Summary. Oestrus was synchronized in twenty-four of twenty-seven heifers with implants having a surface area of $9200 \mathrm{~mm}^{2}$ and containing $4 \mathrm{~g}$ progesterone. Fertility following natural mating was low with only $47 \%$ of mated heifers conceiving. Neither the number of matings up to four nor the time of mating during oestrus increased the conception rate. Reducing the period of administration of progesterone from 20 to 10 days by giving $5 \mathrm{mg}$ oestradiol benzoate on the day of insertion of the implants increased the conception rate to normal but resulted in a lowered oestrous response. Injection of $400 \mu \mathrm{g}$ oestradiol benzoate $16 \mathrm{hr}$ after removal of the implants following a 10-day treatment period did not increase the oestrous response but in fact lowered the conception rate compared to that of uninjected controls. Implants capable of synchronizing heat in heifers were less effective in cyclic dairy cows.
\end{abstract}

\section{INTRODUCTION}

The administration of exogenous progesterone to cows for the duration of a cycle suppresses oestrus and ovulation and the majority of cows show oestrus 2 to 5 days after withdrawal of the progesterone (Lamond, 1964). This method of synchronization of oestrus had been widely used, but the conception rate to matings at the controlled oestrus has been low (Hansel, 1967; Mauléon \& Chupin, 1971). The use of more potent synthetic progestagens has not led to any improvement in fertility (Jochle, 1972).

The dominant rôle of progesterone in regulating the oestrous cycle has been confirmed by recent reports of blood levels of hormones throughout the oestrous cycle (Hansel, 1972). Because progesterone occurs naturally in many body tissues as well as in milk (Heap, Laing \& Walters, 1973) and is also readily available, it is the progestagen of choice for synchronization of oestrus. The high daily amounts of progesterone required to suppress oestrus in cattle (Lamond, 1964) has hindered development of practical methods for synchronization. Silastic rubber implants impregnated with steroids are non-toxic and give a slow continuous release of steroids (Dziuk \& Cook, 1966). Silastic implants impregnated with synthetic progestagens have been shown to be effective in controlling the oestrous cycle of heifers (Roche \& Crowley, 1973). This paper deals with attempts to develop silastic implants capable of releasing sufficient progesterone to synchronize oestrus in cattle. Some factors affecting 
conception rate to matings at the control heat were then examined in synchronized heifers.

\section{MATERIALS AND METHODS}

\section{Implants}

Silastic implants were made up by incorporating $4 \mathrm{~g}$ progesterone into a silicone elastomer (Silcoset 105) and then adding a curing agent. Type I implants had a surface area of $9200 \mathrm{~mm}^{2}$ while Type II implants had a surface area of $4100 \mathrm{~mm}^{2}$. Implants were autoclaved and inserted into the dewlap with the aid of a trocar. They were removed by making a small skin incision and extruding the implant. Implants in the first experiment were weighed before and after insertion in attempts to determine the release rate of progesterone in vivo.

\section{Animals}

The experimental animals, except in the last experiment, were Hereford cross mature non-pregnant heifers purchased locally. The heifers were grazed at pasture during the summer of 1972. Vasectomized bulls, fitted with chin-ball mating devices, were kept with the heifers to aid in the detection of oestrus. Beginning $24 \mathrm{hr}$ after removal of the implants, the heifers in all experiments were individually checked for oestrus every $4 \mathrm{hr}$ for $36 \mathrm{hr}$ with vasectomized bulls. Heifers in oestrus were mated to fertile bulls and killed 30 to 40 days later to determine the pregnancy rate based on presence of live embryos. Two animals in which resorbing embryos were found were classified as not pregnant.

\section{Experiment 1}

Twenty-seven heifers selected at random received Type I implants while fifteen similar animals received Type II implants. Vasectomized bulls were kept with the heifers for 20 days while the implants were in situ. Following removal of the implants, the number of animals in oestrus, the interval from removal of implants to onset of oestrus and the duration of oestrus were determined. Heifers exhibiting oestrus were mated to a fertile bull and then killed. In all subsequent experiments, only Type I implants were used.

\section{Experiment 2}

Thirty-three heifers received Type I implants for 20 days. Following removal of the implants, the heifers were randomly selected as they came into oestrus and mated from one to four times with fertile bulls at 4-hr intervals during oestrus and were subsequently killed.

\section{Experiment 3}

Fifteen heifers were randomly allocated to a short-term, and fifteen to a longterm progesterone treatment. The short-term treatment consisted of exposure to a progesterone implant for 10 days with an injection of $5 \mathrm{mg}$ oestradiol benzoate at time of insertion as described by Wiltbank \& Kasson (1968), while the long-term treatment was the same as that described for the second 
experiment. Heifers in oestrus following withdrawal of the implants were mated twice to fertile bulls, and the number that became pregnant was determined at slaughter.

\section{Experiment 4}

Forty-one heifers, ten of which were diagnosed as having inactive ovaries on the basis of rectal examination, received implants for 10 days and were given $5 \mathrm{mg}$ oestradiol benzoate on the day of insertion of implants. Sixteen hours after removal of the implants, twenty-three heifers, selected at random, were given $400 \mu \mathrm{g}$ of oestradiol benzoate in corn oil. The occurrence of oestrus was determined and the heifers were mated twice during oestrus to a fertile bull. The number pregnant was determined at slaughter.

\section{Experiment 5}

Fifty-nine cyclic Friesian dairy cows, 40 to 65 days after calving, received implants for 18 days. The animals were checked for oestrus twice daily at milking with the aid of a vasectomized bull during treatment. Following removal of the implants, the cows were then inseminated on a fixed-time basis without reference to behavioural oestrus.

\section{Statistics}

Differences between means were tested for significance by means of Student's $t$ test.

\section{RESULTS}

\section{Experiment 1}

None of the heifers was observed to have come into oestrus while the implants were in place. Following removal of Type I implants, the oestrous response was high compared with that obtained with Type II implants (Table 1).

Table 1. Synchronization of heat in heifers with implants of progesterone

\begin{tabular}{|c|c|c|}
\hline & \multicolumn{2}{|c|}{ Surface area of implant $\left(\mathrm{mm}^{2}\right)$} \\
\hline & 9200 & 4100 \\
\hline No. of heifers & 27 & 15 \\
\hline $\begin{array}{l}\text { Heifers in oestrus } \\
\text { No. } \\
\%\end{array}$ & $\begin{array}{l}24 \\
89\end{array}$ & $\begin{array}{l}10 \\
67\end{array}$ \\
\hline $\begin{array}{l}\text { Interval from removal of implant to } \\
\text { onset of oestrus* (hr) }\end{array}$ & $35 \cdot 8 \pm 2 \cdot 60$ & $48 \cdot 8 \pm 8 \cdot 43$ \\
\hline Length of oestrus* (hr) & $10 \cdot 5 \pm 0 \cdot 83$ & $8 \cdot 0 \pm 0 \cdot 78$ \\
\hline $\begin{array}{l}\text { Mated heifers pregnant } \\
\text { No. } \\
\%\end{array}$ & $\begin{array}{l}12 \\
50\end{array}$ & $\begin{array}{r}4 \\
40\end{array}$ \\
\hline Release rate of progesterone* (mg/day) & $29 \pm 2 \cdot 40$ & $17 \pm 0.95$ \\
\hline
\end{tabular}

* Expressed as mean \pm S.E.M. 
The interval from removal of the implants to the onset of oestrus was shorter with Type I implants but the difference was not significant. There was no difference in the duration of oestrus. The conception rate following both treatments was low, only $47 \%$ of heifers conceiving following natural mating. Based on the weight difference between insertion and removal of the implants, Type I and Type II implants released $29 \pm 2.40$ and $17 \pm 0.95 \mathrm{mg}$ progesterone/ day, respectively, and this difference was significant $(P<0.01)$.

\section{Experiment 2}

Increasing the number of matings with the bull from one to four at 4-hr intervals during oestrus did not improve the conception rate (Table 2). It

Table 2. The effect of the number of matings on the conception rate in heifers at the synchronized heat

\begin{tabular}{c|c|cc}
\hline $\begin{array}{c}\text { No. of } \\
\text { matings }\end{array}$ & $\begin{array}{c}\text { No. of heifers } \\
\text { mated }\end{array}$ & \multicolumn{2}{|c}{$\begin{array}{c}\text { Heifers pregnant } \\
\text { No. }\end{array}$} \\
\hline 1 or 2 & 17 & 8 & 47 \\
3 or 4 & 16 & 8 & 50 \\
\hline
\end{tabular}

Table 3. Comparison of 10-day and 20-day treatments with progesterone implants on the oestrous response and conception rate in heifers

\begin{tabular}{|c|c|c|}
\hline & \multicolumn{2}{|c|}{ Length of treatment } \\
\hline & 20 days & 10 days \\
\hline No. of heifers & 15 & 15 \\
\hline $\begin{array}{l}\text { Heifers in oestrus within } 3 \text { days of } \\
\text { removal of implants } \\
\text { No. } \\
\%\end{array}$ & $\begin{array}{l}14 \\
93\end{array}$ & $\begin{array}{l}11 \\
73\end{array}$ \\
\hline $\begin{array}{l}\text { Interval from removal of implants to } \\
\text { oestrus* (hr) }\end{array}$ & $30 \cdot 5 \pm 1 \cdot 75$ & $34.5 \pm 1 \cdot 65$ \\
\hline Duration of oestrus* (hr) & $10 \cdot 0 \pm 1 \cdot 14$ & $12.9 \pm 1.08$ \\
\hline $\begin{array}{l}\text { Mated heifers pregnant } \\
\text { No. } \\
\%\end{array}$ & $\begin{array}{r}8 \\
57\end{array}$ & $\begin{array}{r}9 \\
82\end{array}$ \\
\hline
\end{tabular}

was also evident that the time of mating during oestrus did not affect the conception rate since animals mated three or four times were served at different times during oestrus.

\section{Experiment 3}

The oestrous response in the heifers on the 10-day progesterone treatment was low (eleven of fifteen in oestrus), but the conception rate to mating of those heifers that did show oestrus was normal. This contrasted with the high 
oestrous response (fourteen of fifteen in oestrus) and low conception rate in the heifers which received progesterone for 20 days. There were no differences in the interval from removal of the implants to the onset of oestrus or in the duration of oestrus between the two treatments.

\section{Experiment 4}

Injection of a small physiological dose of oestradiol benzoate $(400 \mu \mathrm{g}) 16 \mathrm{hr}$ after removal of the implants following the short-term treatment with progesterone did not increase the oestrous response to the level obtained in the heifers with implants retained for 20 days in Exps 2 and 3 (Table 4). The

Table 4. Effect of oestradiol benzoate $16 \mathrm{hr}$ after removal of implants from heifers on a 10-day progesterone treatment

\begin{tabular}{l|c|c}
\hline & Controls & $\begin{array}{c}\text { Oestradiol benzoate } \\
(400 \mu \mathrm{g})\end{array}$ \\
\hline $\begin{array}{l}\text { No. of heifers } \\
\text { Heifers in oestrus within 3 days of } \\
\text { removal of implants }\end{array}$ & 18 & 23 \\
$\quad$ No. & 10 & 15 \\
$\quad \%$ & 56 & 65 \\
$\begin{array}{l}\text { Interval from removal of implants to } \\
\text { onset of oestrus* (hr) }\end{array}$ & $31 \cdot 1 \pm 1 \cdot 29$ & $26 \cdot 1 \pm 1 \cdot 76$ \\
$\begin{array}{l}\text { Duration of oestrus* (hr) } \\
\text { Mated heifers pregnant } \\
\text { No. }\end{array}$ & $12 \cdot 1 \pm 1 \cdot 85$ & $14 \cdot 6 \pm 2 \cdot 13$ \\
$\%$ & 8 & 6 \\
\hline
\end{tabular}

* Expressed as mean \pm S.E.M.

conception rate was reduced however, in those heifers which received $400 \mu \mathrm{g}$ oestradiol benzoate $16 \mathrm{hr}$ after removal of the implants (Table 4).

\section{Experiment 5}

Insertion of Type I implants into cyclic dairy cows did not result in complete suppression of oestrus during the 18-day period of treatment. Of fifty-nine cows with implants, fourteen showed oestrus. The remaining forty-five cows were inseminated on a fixed-time basis. Cows that did not hold to the fixedtime insemination had repeat oestrous periods 18 to 23 days later. The treatment induced synchronization of oestrus in these forty-five cows with Type I implants.

\section{DISCUSSION}

The implants with the larger surface area were more effective in synchronizing oestrus than the implants with the same concentration of progesterone but half the surface area. This finding is in agreement with that of Dziuk \& Cook (1966) who reported that surface area is more important than concentration in determining release rate from silastic implants. The large surface area required to release sufficient progesterone to suppress oestrus and ovulation, 
even in heifers, does not favour the use of subcutaneous implants containing progesterone in cattle. If progesterone is to be used, alternative routes of administration will have to be investigated. Intravaginal pessaries containing progestagens, which are highly effective in sheep, have been used in cattle but the retention rate has been reported to be variable (Carrick \& Shelton, 1967; Wishart \& Hoskin, 1968; Mauléon \& Chupin, 1971). More research is required to obtain pessaries with high retention rates (Scanlon, Sreenan \& Gordon, 1972 ) or to develop intravaginal silastic implants similar to those used in humans (Mishell, Talas, Parlow \& Moyer, 1970).

Despite the high degree of synchronization obtained with the present implants, the conception rate following natural mating was low and similar to results reported previously by others (Hansel, 1967; Mauléon \& Chupin, 1970; Jochle, 1972). Many factors have been implicated in this low conception rate in cattle and sheep, such as poor sperm transport (Quinlivan \& Robinson, 1969), increased 'breakage' of spermatozoa (Hawk \& Conley, 1971), imbalance in the secretory pattern of hormones in plasma at this time (Hill, Lamond, Henricks, Dickey \& Niswender, 1971; Rodeffer, Hopwood \& Wiltbank, 1972), and low fertilization rate (Hill et al., 1971). It has been shown that rams placed with oestrous ewes at the time of pessary removal exhaust themselves in the first few matings. By ensuring that each oestrous ewe is hand-mated to a ram of high fertility, Jennings \& Crowley (1972) have reported normal fertility in ewes induced to mate in late anoestrus. Hand-mating heifers from one to four times during oestrus in our experiments, however, did not improve the conception rate. It appears that cows differ from ewes in that high sperm numbers do not overcome the low conception rate obtained to matings at the controlled oestrus in synchronized animals. This apparent species difference emphasizes the difficulties that occur in extrapolating results from one species to another in relation to endocrine phenomena.

When oestrus was synchronized in heifers by feeding a progestagen for 9 days and injecting oestradiol valerate on the 2nd day of progestagen feeding to induce luteal regression, the conception rate was comparable to that in controls (Wiltbank \& Kasson, 1968). Rodeffer et al. (1972) found that the prooestrous oestrogen peak occurred about $12 \mathrm{hr}$ after the LH peak in heifers synchronized with progesterone for 18 days which was in marked contrast to the situation in control heifers or heifers synchronized after the 9-day treatment. Thus, abnormal oestrogen patterns may be a contributory factor in the low conception rate following an 18-day progesterone treatment. The results of these experiments using the 10-day treatment regimen support the fact that fertility is normal in heifers mated at the controlled oestrus. With the shortterm treatment, however, the oestrous response was reduced from that obtained in similar heifers given progesterone for 20 days. The reasons for this lowered oestrous response are not immediately clear. It is possible that the oestrogen given to animals in the follicular stage of the oestrous cycle is either causing premature ovulation or that oestrogen is ineffective in causing complete luteal regression. Hansel (1972) claimed that single doses of oestradiol valerate have only a limited capacity to cause luteal regression and a decline in plasma progesterone in heifers. Neither Wiltbank \& Kasson (1968) nor Wiltbank, 
Sturges, Wideman, Le Fever \& Faulkner (1971), however, reported that the oestrous response was lower with the short-term treatment and thus the various progestagens could differ in this respect.

It has been shown that oestrogen is responsible for the release of the ovulatory surge of LH in cows (Hobson \& Hansel, 1972). Small amounts of oestrogen given at the time of removal of the corpus luteum on Days 13 to 15 of the cycle in heifers also hastened the onset of oestrus and the LH surge as well as giving a shorter LH surge. Hansel (1972) also found that $400 \mu \mathrm{g}$ oestradiol benzoate given $20 \mathrm{hr}$ after the last feeding of 17-medroxyprogesterone acetate significantly hastened the onset of oestrus and also resulted in a normal conception rate. When $400 \mu \mathrm{g}$ oestradiol benzoate were given to heifers $16 \mathrm{hr}$ after removal of the implants in these experiments, the conception rate was reduced compared to that of synchronized heifers not receiving oestrogen after removal of implants. Reduced conception rates have been reported in ewes synchronized with pessaries containing progestagens and oestradiol (Gordon, 1971) and in cattle when $2 \mathrm{mg}$ oestrogen is given after a 9-day treatment with norethandrolone (Wiltbank et al., 1971). Whether changing the time of injection of oestrogen relative to implant removal would change the fertility level obtained has not been tested. If oestrogen is to be used after a progestagen treatment, then the dose and time of administration are both critical in determining conception rate.

The practical value of oestrous synchronization regimens depends on their effectiveness in lactating cows as well as in heifers. Silastic implants that are capable of synchronizing heat in cyclic heifers were not as effective in cyclic dairy cows. This would indicate that the dose of exogenous progesterone required to suppress oestrus in dairy cows is higher than that required in heifers. This could be due to the larger body size, but it is also possible that the endocrine interactions are different. Thus, synchronizing treatments effective in heifers may not necessarily be as successful in lactating dairy cows.

\section{AGKNOWLEDGMENTS}

The author wishes to thank Dr F. J. Harte and Dr J. Walsh for facilities provided and $\mathrm{Mr}$ D. Prendiville and Mr M. Dolan for excellent technical assistance provided.

\section{REFERENCES}

Garrick, M. J. \& Shelton, J. N. (1967) The synchronization of oestrus in cattle with progestagenimpregnated intravaginal sponges. F. Reprod. Fert. 14, 21.

Dziuk, P. J. \& Cook, B. (1966) Passage of steroids through silicone rubber. Endocrinology, 78, 208.

GoRDON, I. (1971) Intravaginal oestradiol-progestagen treatments in the induction of early breeding in sheep. 7. agric. Sci., Camb. 76, 355.

Hansel, W. (1967) Control of the ovarian cycle in cattle. In Reproduction in the Female Mammal, Proc. 13th Easter School, University of Nottingham, p. 419. Eds. G. E. Lamming and E. C. Amoroso. Butterworth, London.

HANsel, W. (1972) Bio-technical procedures for control of the estrous cycles of domestic animals. Proc. 7th Int. Congr. Anim. Reprod. \& A.I., Munich, 1, 75.

HAWK, H. W. \& Conley, H. H. (1971) Loss of spermatozoa from the reproductive tract of the ewe and intensification of sperm 'breakage' by progestagen. F. Reprod. Fert. 27, 339. 
Heap, R. B., Laing, M. G. J. A. \& Walters, D. E. (1973) Pregnancy diagnosis in cows; changes in milk progesterone concentration during the oestrous cycle and pregnancy measured by a rapid radioimmunoassay. F. agric. Sci., Camb. 81, 151.

Hill, J. R., Lamond, D. R., Henricks, D. M., Dickey, J. F. \& Niswender, G. D. (1971) The effects of melengestrol acetate (MGA) on ovarian function and fertilization in beef heifers. Biol. Reprod. 4, 16.

Hobson, W. G. \& Hansel, W. (1972) Plasma LH levels after ovariectomy, corpus luteum removal and estradiol administration in cattle. Endocrinology, 91, 185.

Jennings, J. J. \& Growley, J. P. (1972) The influence of mating management on fertility in ewes following progesterone-PMS treatment. Vet. Rec. 90, 495.

Jochle, W. (1972) Pharmacological aspects of the control of the cycle in domestic animals. Proc. 7 th Int. Congr. Anim. Reprod. \& A.I., Munich, 1, 97.

Lamond, D. R. (1964) Synchronization of ovarian cycles in sheep and cattle. Anim. Breed. Abstr. 32, 269.

Maulḱon, P. \& Chupin, D. (1971) Maitrise des cycles sexuels chez les bovins. Écon. Méd. anim. 12, 31.

Mishell, D. R., Talas, M., Parlow, A. F. \& Moyer, D. L. (1970) Contraception by means of a silastic vaginal ring impregnated with medroxyprogesterone acetate. Am. F. Obstet. Gynec. 107, 100.

Quinlivan, T. D. \& Robinson, T. J. (1969) Numbers of spermatozoa in the genital tract after artificial insemination of progestagen-treated ewes. 7. Reprod. Fert. 19, 73.

Roche, J. F. \& Crowley, J. P. (1973) The fertility of heifers inseminated at predetermined intervals following treatment with MGA and HCG to control ovulation. F. Reprod. Fert. 35, 211.

Rodeffer, G. H., Hopwood, M. L. \& Wiltbank, J. N. (1972) LH and estrogens following estrous control. F. Anim. Sci. 34, 901.

SGanlon, P. F., SREenan, J. \& GoRdon, I. (1972) Observations on the retention of intravaginal sponge pessaries by cattle. Vet. Rec. $90,437$.

Wiltbank, J. N. \& Kasson, G. W. (1968) Synchronization of estrus in cattle with an oral progestational agent and an injection of an estrogen. 7. Anim. Sci. 27, 113.

Wiltbank, J. N., Sturges, J. G., Wideman, D., Le Fever, D. G. \& Faulkner, L. G. (1971) Control of estrus and ovulation using subcutaneous implants and estrogens in beef cattle. F. Anim. Sci. 33,600 .

Wishart, D. F. \& Hoskin, B. D. (1968) Synchronization of oestrus in heifers using intra-vaginal pessaries impregnated with SC-9880 and PMSG. F. Reprod. Fert. 17, 285. 